\title{
Seosrehu pilaantuu nopeasti jos vanhaa seosta jää mukaan
}

\author{
Arja Seppälä ${ }^{1)}$, Terttu Heikkilä ${ }^{1)}$, Marketta Rinne ${ }^{1)}$ ja Harri Miettinen ${ }^{2)}$ \\ ${ }^{1)}$ MTT Kotieläintuotannon tutkimus, 31600 Jokioinen, etunimi.sukunimi@mtt.fi \\ ${ }^{2)}$ Kemira Oyj, ChemSolutions, Feed, P.O. Box 330,FI-00101 Helsinki, etunimi.sukunimi@kemira.com
}

\section{Tiivistelmä}

Seosrehuruokinnassa erityisesti kesäaikana rehuseoksen lämpeneminen ruokintapöydällä on tavallinen ongelma. Säilörehun aerobisesta stabiilisuudesta tehtyjen tutkimusten ja käytännön havaintojen perusteella on syytä olettaa, että lämpenemisongelma seosrehuruokinnassa kärjistyy erillisruokintaan verrattuna. Tässä kokeessa havainnollistettiin, miten $10 \%$ osuus vanhaa rehua uudessa seoksessa vaikuttaa tehdyn seosrehun pilaantumisherkkyyteen. Lisäksi tutkittiin mahdollisuutta hidastaa seosrehun pilaantumista ruokintatilanteessa propionihappopohjaisilla säilöntäaineilla.

Kokeessa käytetty seosrehu sisälsi 37 \% väkirehuseosta ja 63 \% säilörehua kuiva-aineesta. Pelletöity väkirehuseos sisälsi ohraa, kauraa, melassileikettä, rypsipuristetta ja kivennäisiä. Säilörehu oli toisen sadon timotei-nurminata-puna-apilanurmea, joka oli säilötty muurahaishappopohjaisella säilöntäaineella. Säilörehun säilönnällinen laatu oli kiitettävä. Seosrehun kuiva-ainepitoisuus oli 409 g/kg ka. Samalla reseptillä tehtiin kaksi seosrehua. Tuore seos sekoitettiin puhtaalla seosrehun sekoituslaitteella hyvälaatuisista raaka-aineista. Tuoreen seoksen lisäksi tehtiin seos, jossa käytettiin ymppinä 10 \% jo lämmennyttä seosta. Ymppinä käytetty seosrehu oli sekoitettu samalla reseptillä viikkoa aikaisemmin ja sen oli annettu lämmetä.

Välittömästi seosrehujen sekoittamisen jälkeen niihin lisättiin kokeessa tutkitut säilöntäaineet. Kiinteä tuote sisälsi natriumkalsiumpropionaattia ja nestemäinen tuote propionihappoa, ammoniumpropionaattia ja ammoniumformiaattia. Aineita lisättiin kahdella eri annostustasolla (2 tai $3 \mathrm{~g} / \mathrm{kg}$ ). Kustakin käsittelystä tehtiin kolme rinnakkaista rehunäytettä, joiden lämpenemistä seurattiin 6 vuorokauden ajan. Rehunäytteiden aerobinen stabiilisuus ja kuiva-ainetappiot aerobisen vaiheen aikana määritettiin.

Vanha seosrehu uuden seosrehun seassa lyhensi aerobista stabiilisuutta reilulla kahdella vuorokaudella (9,2 h vs. 66,2 h, p < 0,001). Tutkituilla säilöntäaineilla voitiin parantaa seosrehun aerobista stabiilisuutta tässä kokeessa keskimäärin 3,2 tuntia ilman säilöntäainetta tehtyyn kontrollikäsittelyyn verrattuna $(\mathrm{p}<0,001)$. Säilöntäaineiden tai annostelutasojen välillä ei ollut tilastollisesti merkitseviä eroja. Tämän kokeen tulos osoittaa selvästi, miten merkittävää seosrehun laadun kannalta on, ettei pilaantuneen vanhan rehun anneta ympätä tuoretta seosta.

Asiasanat: seosrehu, aerobinen stabiilisuus, jälkilämpeneminen, propionihappo, natriumkalsiumpropionaatti ammoniumpropionaatti, ammoniumformiaatti 


\section{Johdanto}

Seosrehuruokinnan ohjeistuksessa on korostettu hygienian sekä laadukkaiden raaka-aineiden tärkeyttä. Käytännössä kuitenkin seosrehun lämpeneminen ruokintapöydällä on Suomenkin oloissa tavallinen ilmiö erityisesti kesäaikaan. Lämpeneminen on merkki rehun pilaantumisesta. Pilaantuminen aiheuttaa ravintoainetappioita, heikentää rehun maittavuutta ja pienentää tuotosta (Kung 2005). Lämpenemisen vaikutusta oman karjan tuotokseen on kuitenkin vaikea havaita, sillä yleensä tarjolla on vain yhtä seosta kerrallaan. Toistaiseksi nurmisäilörehuun perustuvalla ruokinnalla tehtyjä mittauksia seosrehun lämpenemisen vaikutuksesta syöntiin tai tuotokseen ei ilmeisesti ole. Näin ollen ilmiön taloudellista vaikutusta voidaan vain arvailla.

Rehun aerobinen stabiilisuus tarkoittaa aikaa, jonka rehu säilyy pilaantumatta ja lämpenemättä sen jälkeen, kun ilmaa pääsee rehun sekaan siilon avaamisen yhteydessä (Kung 2005). Tutkimuksissa (ks. Broderick ym. 2009) aerobisen stabiilisuuden päättymisen raja-arvona on pidetty 2 tai 3 asteen lämpötilan nousua ympäristöön verrattuna. Säilörehun aerobista stabiilisuutta on tutkittu runsaasti 1970-luvun alusta lähtien. Tutkimuksen avulla on pyritty selittämään eroja rehujen aerobisessa stabiilisuudessa sekä löytämään lisäaineita tai mikrobikantoja, joiden avulla säilörehun aerobista stabiilisuutta voitaisiin parantaa (McDonald 1991, Pahlow ja Muck 2009).

Säilörehun aerobisen pilaantumisen aloittavat tavallisesti hiivat, joiden toiminnan tuloksena olosuhteet muuttuvat sellaisiksi, että myös muut aerobiset pilaajamikrobit pystyvät lisääntymään rehussa. Aerobinen pilaantuminen on sukkessio, jossa aerobiset mikrobipopulaatiot hajottavat rehun orgaanisia aineita. Ensin hajotetaan helposti sulavat hiilihydraatit ja orgaaniset hapot. Pilaantumisen edetessä mikrobit voivat hajottaa myös valkuaista ja kuitua (McDonald ym. 1991, Kung 2005).

Seosrehussa olosuhteet ovat aerobiselle pilaantumiselle suotuisat. Happea sekoitetaan rehumassaan rehun sekoituksen yhteydessä. Helppoliukoisia hiilihydraatteja kuten tärkkelystä lisätään seokseen. Aerobisia pilaajamikrobeja tulee seokseen rehukomponenttien mukana ja sekoitus varmistaa mikrobien leviämisen koko massaan. Kesäaikaan lämpö parantaa hiivojen kasvuedellytyksiä talviaikaan verrattuna. Näin ollen on oletettavaa, että seosrehu lämpenee ruokintatilanteessa nopeammin kuin säilörehu erillisruokintana.

Mietittäessä keinoja seosrehun aerobisen stabiilisuuden parantamiseen pitäisi tuntea ongelman taloudellinen merkitys ja sen jälkeen voidaan arvioida eri toimenpiteiden taloudellinen mielekkyys. Hoffman ja Ocker (1997) syöttivät lehmille joko tuoreista raaka-aineista tehtyä seosrehua tai seosrehua, jonka raaka-aineesta 33 \% kuiva-aineesta oli aerobisessa tilassa 1-14 vrk säilytettyä maissia. Aerobisesti pilaantunutta rehua saaneiden eläinten maitotuotos laski 3,2 kg, vaikka rehun syönti ei muuttunut. Tuon viitteen perusteella panostaminen rehun hyvään aerobiseen stabiilisuuteen on taloudellisesti erittäin perusteltua.

Seosrehun heikko aerobinen stabiilisuus voi olla peräisin säilörehun heikosta aerobisesta stabiilisuudesta tai esimerkiksi pilaantuneiden sivutuotteiden lisäämisestä rehuun (Kung 2005). Ongelman perimmäinen syy kannattaa pyrkiä löytämään ja korjaamaan. Mikäli se ei onnistu tai riitä, tulee kyseeseen säilyvyyttä parantavien lisäaineiden lisääminen suoraan seosrehuun. Propionihappopohjaisia tuotteita on käytetty tässä tarkoituksessa, sillä ne ehkäisevät tehokkaasti hiivojen ja homeiden kasvua (Kung 2005).

Tässä kokeessa havainnollistettiin, miten $10 \%$ osuus vanhaa rehua uudessa seoksessa vaikuttaa tehdyn seosrehun pilaantumisherkkyyteen. Lisäksi tutkittiin mahdollisuutta hidastaa seosrehun pilaantumista ruokintatilanteessa propionihappopohjaisilla säilöntäaineilla.

\section{Aineisto ja menetelmät}

\section{Koejärjestely}

Koe suoritettiin MTT:ssä Jokioisilla kesäkuussa 2009. Kokeessa käytettiin kahta seosrehua eli tuoretta seosta puhtaana ja ympättynä 10 \%:lla lämmennetty seosta. Seosrehujen lämpenemisherkkyyttä mitattiin ilman säilöntäaineita ja kiinteää tai nestemäistä säilöntäainetta käyttäen. Molempia säilöntäaineita käytettiin kahdella eri annostustasolla. Jokaisesta käsittelystä tehtiin kolme rinnakkaista. Koejärjestely on esitetty kuvassa 1. 


\section{Seosrehun valmistus}

Kokeessa käytetty seosrehu sisälsi 37 \% väkirehuseosta ja 63 \% säilörehua kuiva-aineesta. Pelletöidyn väkirehuseoksen resepti on Taulukossa 1. Säilörehu oli kesän 2008 toisen sadon timotei-nurminatapuna-apilanurmea, joka oli säilötty muurahaishappopohjaisella (AIV 2 Plus) säilöntäaineella. Säilörehun säilönnällinen laatu oli kiitettävä (Taulukko 2).

Taulukko 1. Väkirehun koostumus

\begin{tabular}{lc}
\hline Komponentti & Osuus, \% \\
\hline Ohra & 30,1 \\
Kaura & 30,0 \\
Melassileike & 10,9 \\
Rypsipuriste & 25,9 \\
Onni-kivennäinen & 3,0 \\
Suola & 0,1 \\
\hline
\end{tabular}
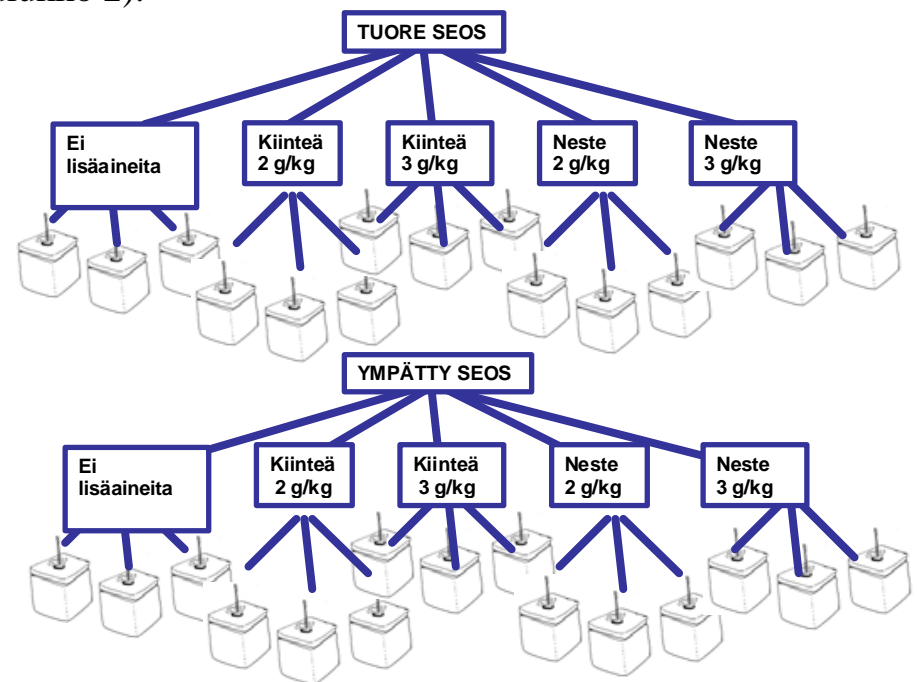

Kuva 1. Koejärjestely.

Taulukko 2. Kokeessa käytettyjen rehujen koostumus ja säilönnällinen laatu.

\begin{tabular}{|c|c|c|c|c|}
\hline & Väkirehu & $\begin{array}{c}\text { Seoksessa käytetty } \\
\text { säilörehu }\end{array}$ & Seosrehu & $\begin{array}{l}\text { Ymppimateriaalina } \\
\text { käytetty seosrehu }\end{array}$ \\
\hline Kuiva-aine, g/kg & 887 & 315 & $409^{1)}$ & 363 \\
\hline \multicolumn{5}{|l|}{$\begin{array}{l}\text { Kuiva-aineessa, } \\
\text { g/kg ka }\end{array}$} \\
\hline Tuhka & & 92,3 & 86,3 & \\
\hline Raakavalkuainen & & 121 & 142 & \\
\hline Kuitu & & 499 & 394 & \\
\hline Tärkkelys & & & 114 & \\
\hline D-arvo & & 644 & & \\
\hline Sokerit & & 93,3 & & 8,5 \\
\hline Maitohappo & & 52,3 & & 51,3 \\
\hline Muurahaishappo & & 14,4 & & 0 \\
\hline Etanoli & & 8,4 & & 0 \\
\hline Etikkahappo & & 14,2 & & 11,2 \\
\hline Propionihappo & & 0 & & 0,33 \\
\hline Voihappo & & 0,13 & & 0,36 \\
\hline Isovoihappo & & 0 & & 0,11 \\
\hline Valeriaanahappo & & 0 & & 0,03 \\
\hline Isovaleriaanahappo & & 0,13 & & 0,14 \\
\hline Kapronihappo & & 0 & & 0,06 \\
\hline $\mathrm{NH}_{4}-\mathrm{N} \mathrm{g} / \mathrm{kg} \mathrm{N}$ & & 49 & & 0,29 \\
\hline $\mathrm{pH}$ & & 4,15 & & 5,02 \\
\hline
\end{tabular}

${ }^{1)}$ Seosrehun kuiva-ainepitoisuudessa on huomioitu säilörehun haihtuvien aineosien vaikutus.

${ }^{2)}$ Määritetty in vitro pepsiini-sellulaasimenetelmällä

Samalla reseptillä tehtiin kaksi seosrehua. Tuore seos sekoitettiin puhtaalla seosrehun sekoituslaitteella hyvälaatuisista raaka-aineista. Tuoreen seoksen lisäksi tehtiin seos, jossa käytettiin ymppinä $10 \%$ jo lämmennyttä seosta. Ymppinä käytetty seosrehu oli sekoitettu samalla reseptillä viikkoa aikaisemmin. Ymppimateriaalissa havaittiin silmämääräisessä tarkastelussa hiivatäpliä ja pieni pesäke sinistä homekasvustoa (Kuva 2). Ymppimateriaalin väri ei kuitenkaan ollut merkittävästi muuttunut alkuperäisen seoksen väristä, joten voidaan olettaa maatilamittakaavassa tällaista materiaalia voivan joutua seosrehun sekaan. Seosrehu sekoitettiin MTT:n Koe-eläintallilla olevalla tutkimuskäyttöön valmistetulla 
seosrehun sekoituslaitteella. Ymppi eli viikon vanha seos sekoitettiin käsin osaan vasta sekoitetusta seosrehusta. Näin käsiteltäviä seosrehuja oli kaksi: tuore seos ja ympätty seos.

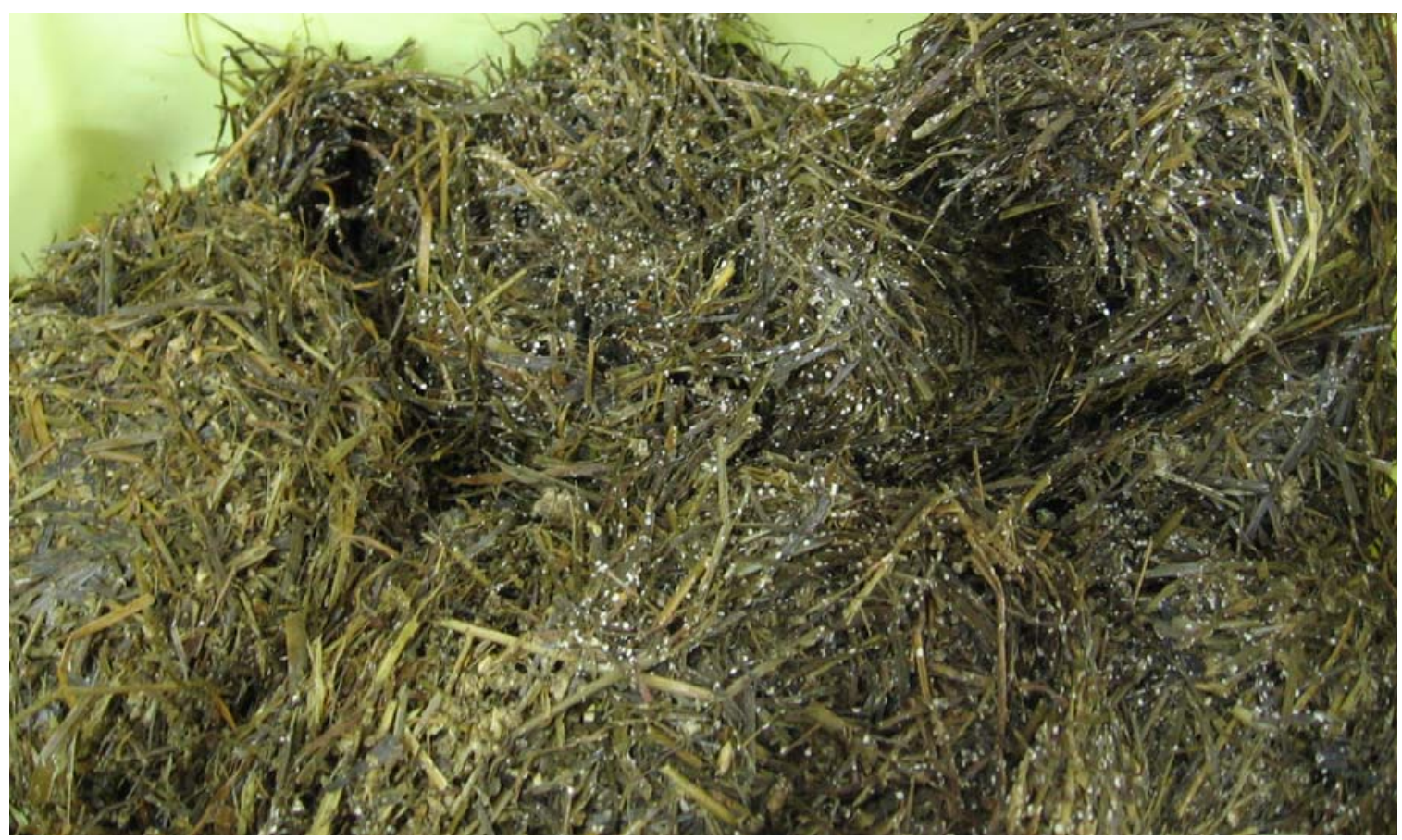

Kuva 2. Viikon vanhaa seosrehua, jota käytettiin kokeessa ymppimateriaalina. Valkeat täplät ovat mikrobikasvustoa, todennäköisesti hiivoja.

Välittömästi seosrehujen sekoittamisen jälkeen niihin lisättiin kokeessa tutkitut säilöntäaineet. Kiinteä tuote sisälsi natriumkalsiumpropionaattia (Kuva 3) ja nestemäinen tuote propionihappoa, ammoniumpropionaattia ja ammoniumformiaattia. Aineita lisättiin kahdella eri annostustasolla (2 tai 3 $\mathrm{g} / \mathrm{kg})$.

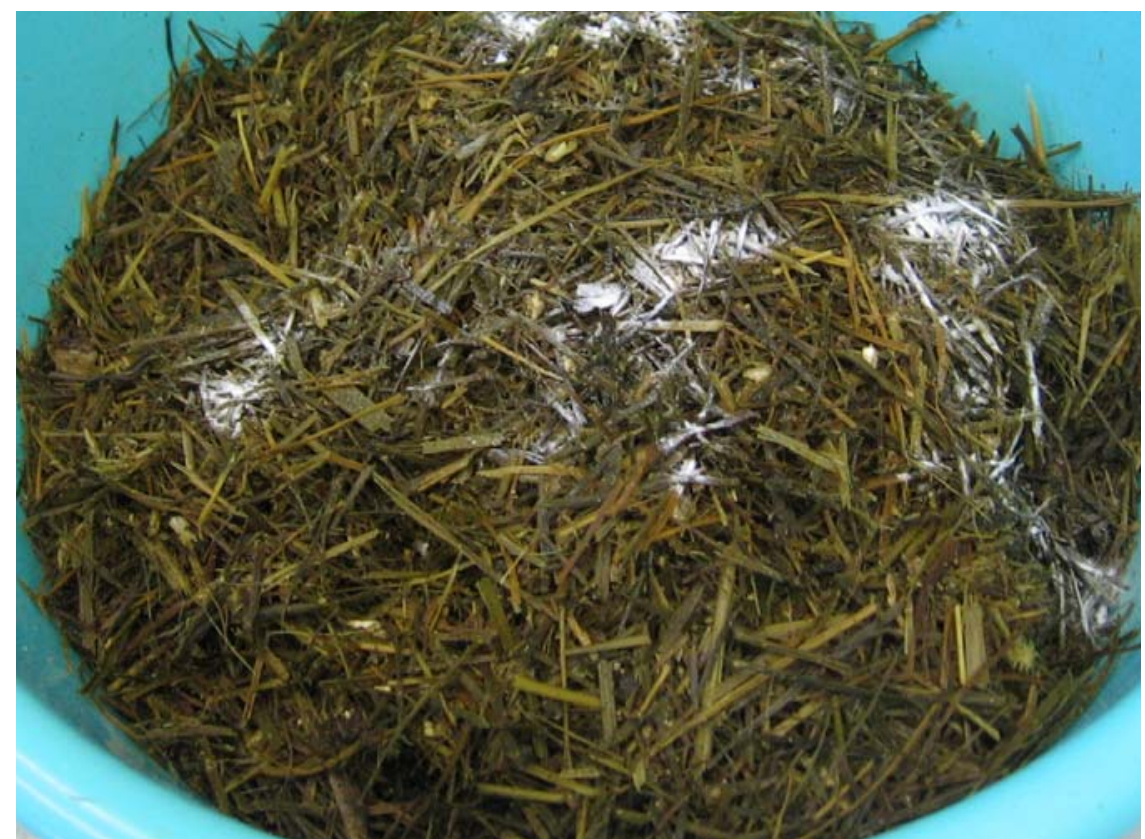

Kuva 3. Seosrehua, johon on juuri lisätty kiinteä säilöntäaine. Tämän jälkeen rehu sekoitettiin huolellisesti. 


\section{Aerobisen stabiilisuuden mittaus}

Seosrehujen lämpenemisherkkyys määritettiin seuraamalla rehun lämpötilan muutosta sen joutuessa ilman vaikutuksen alaiseksi eli hapellisiin olosuhteisiin. Rehunäyte (600 g) laitettiin kaksinkertaiseen muovipussiin, joka sijoitettiin välittömästi styroxlaatikkoon (ulkomitat: $16 \times 16 \times 13,4 \mathrm{~cm}$, seinän paksuus $1,5 \mathrm{~cm})$. Ilma pääsi rehuun kannessa olevan aukon kautta $(\varnothing 3,5 \mathrm{~cm})$, josta lämpötila-anturi laitettiin rehuun. Laatikot sijoitettiin kahteen kaappiin. Rehujen lämpötilan kehitystä seurattiin lämpötila-antureiden avulla lähes kuuden vuorokauden ajan, jotta havaittiin myös ymppäämättömien rehujen lämpeneminen. Lämpötilat kirjattiin kaksi kertaa vuorokaudessa. Lämpötilamittauksista laskettiin kullekin mittauspaikalle rehun aerobinen stabiilisuus eli aika, jonka rehun lämpötila pysyi alle kolme astetta ympäristön lämpötilaa korkeampana.

Lämpötilaseurannan jälkeen kirjattiin aistinvaraiset arviot näytteiden pilaantumisesta. Rehunäytteet myös punnittiin ja niiden kuiva-ainepitoisuus määritettiin. Kuiva-ainetappio jälkilämpenemisen aikana määritettiin alku- ja loppupainojen erotuksena. Kuiva-ainetappioiden laskennassa haihtuvien aineosien osuutta ei huomioitu, joten todellisuudessa osa tappioista jäi täten huomioimatta.

\section{Tilastollinen analysointi}

Käsittelyjen vaikutus rehun aerobiseen stabiilisuuteen ja kuiva-ainetappioihin testattiin SAS GLMproseduurilla. Tilastollisessa mallissa selittäjinä olivat seosrehu, käsittely ja niiden yhdysvaikutus. Käsittelyjen vaikutusta aerobiseen stabiilisuuteen selvitettiin kontrastien avulla (kontrollikäsittely vs. säilöntäainekäsittelyt, annostelutason vaikutus kummallakin aineella erikseen sekä nestemäinen aine vs. kiinteä aine).

\section{Tulokset}

Vanha seosrehu uuden seosrehun seassa lyhensi aerobista stabiilisuutta reilulla kahdella vuorokaudella (9,2 h vs. 66,2 h, p < 0,001, Kuva 4). Tutkituilla säilöntäaineilla voitiin parantaa seosrehun aerobista stabiilisuutta tässä kokeessa keskimäärin 3,2 tuntia kontrollikäsittelyyn verrattuna ( $<<0,001)$. Säilöntäaineiden tai annostelutasojen välillä ei ollut tilastollisesti merkitseviä eroja (Taulukot 3 ja 4).

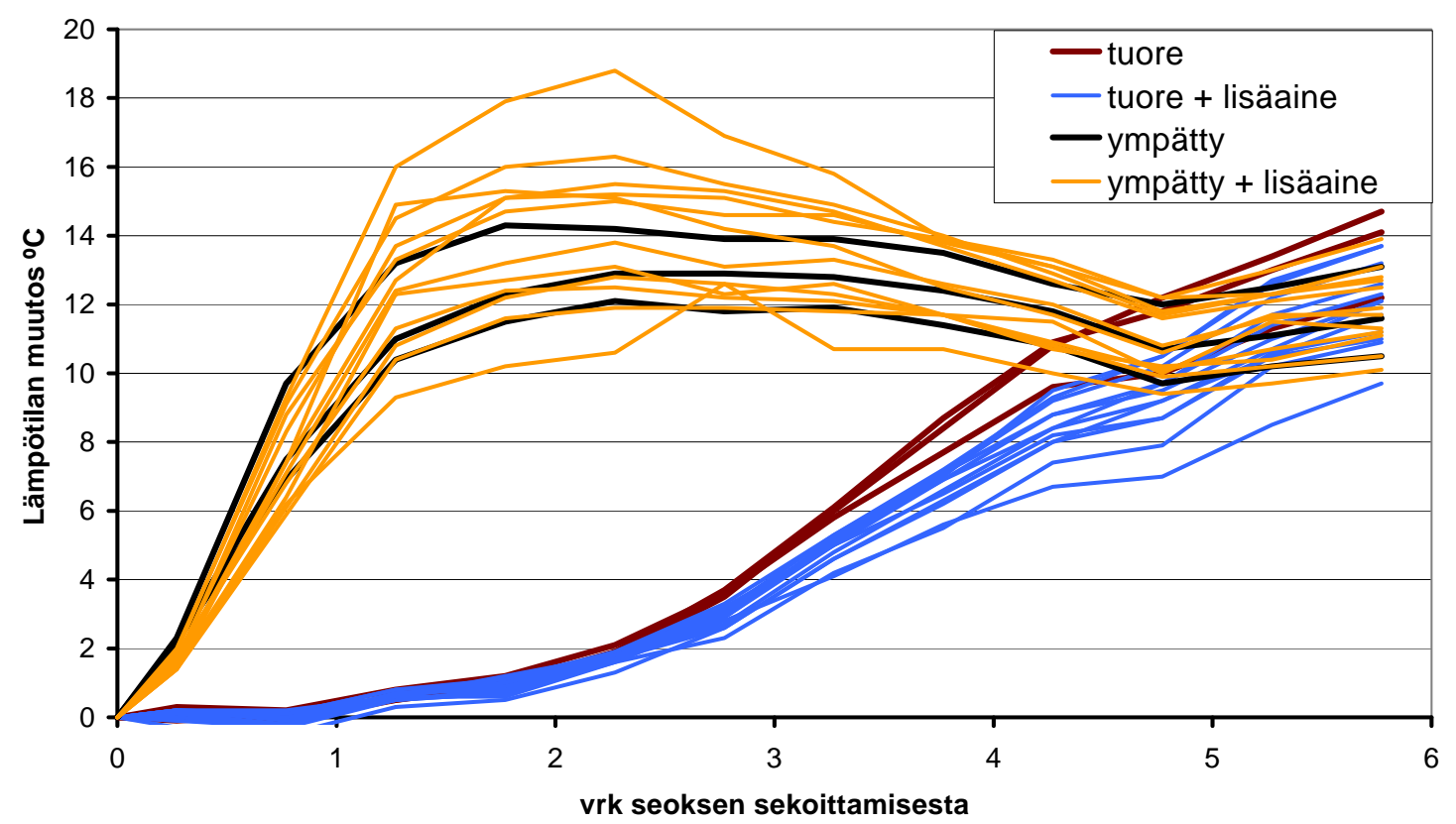

Kuva 4. Seosrehujen lämpötilan muutokset seoksen valmistuksen jälkeen. 
Taulukko 3. Koekäsittelyjen vaikutus seosrehujen aerobiseen stabiilisuuteen.

\begin{tabular}{|c|c|c|c|c|c|c|}
\hline & \multirow[t]{2}{*}{ Keskimäärin } & \multirow{2}{*}{$\begin{array}{l}\text { Ei säilöntä- } \\
\text { ainetta }\end{array}$} & \multicolumn{2}{|c|}{ Nestemäinen aine } & \multicolumn{2}{|c|}{ Kiinteä aine } \\
\hline & & & $2 \mathrm{~g} / \mathrm{kg}$ & $3 \mathrm{~g} / \mathrm{kg}$ & $2 \mathrm{~g} / \mathrm{kg}$ & $3 \mathrm{~g} / \mathrm{kg}$ \\
\hline & \multicolumn{6}{|c|}{ 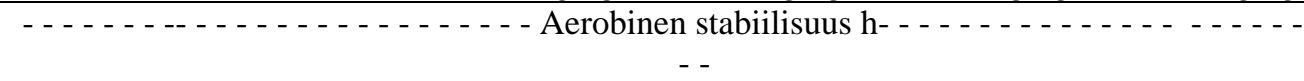 } \\
\hline Tuore seos & 66,2 & 62,2 & 66,6 & 66,7 & 67,5 & 68,3 \\
\hline Ympätty seos & 9,2 & 8,2 & 9,7 & 9,4 & 9,6 & 9,3 \\
\hline Keskivirhe & 0,39 & 0,87 & 0,87 & 0,87 & 0,87 & 0,87 \\
\hline
\end{tabular}

Taulukko 4. Koekäsittelyjen vaikutus seosrehujen aerobiseen stabiilisuuteen, tilastolliset merkitsevyydet.

\begin{tabular}{llc}
\hline \multicolumn{2}{l}{ Tilastollinen merkitsevyys } & Merkitsevyys \\
\cline { 2 - 2 } & Seosrehu & $* * *$ \\
& Säilöntäainekäsittely & $* *$ \\
& Yhdysvaikutus & o \\
Kontrastit & Ei säilöntäainetta vs. säilöntäaineet & $* * *$ \\
& Nestemäinen aine vs. kiinteä aine & NS \\
& Nestemäinen aine, annostelutaso & NS \\
& Kiinteä aine, annostelutaso & NS \\
\hline
\end{tabular}

Seosrehun ymppääminen vanhalla seoksella suurensi kuiva-ainetappiota rehun aerobisen säilytyksen aikana (Kuiva-ainetappio 112 g/kg ka vs. 89,9 g/kg ka, p< 0,01). Huomionarvoista on, että kuivaainetappiot määritettiin vasta lämpötilaseurannan päätyttyä, eli lähes kuuden vuorokauden jälkeen. Tuohon mennessä myös puhdas seos oli lämmennyt, eikä lämpötiloissa ollut enää eri seosrehujen välillä eroa. Jos kuiva-ainetappiot olisi määritetty siinä vaiheessa kun ympätty seos oli jo lämmennyt mutta puhdas seos ei, olisi ero puhtaan seoksen hyväksi ollut vielä selvempi.

Lämpötilamittausten jälkeen rehujen laatua tarkasteltiin myös aistinvaraisesti. Erityisesti ympättyjen rehujen haju todettiin pahaksi, vaikkei rehuja varsinaisesti haisteltu terveyshaittojen välttämiseksi. Näytteiden käsittelyn loppuvaiheessa todettiin myös, että näytteistä erittyvät haihtuvat yhdisteet alkoivat ärsyttää silmiä. Selvimmin rehuja pystyttiin aistinvaraisesti luokittelemaan hiivakasvustojen määrän perusteella, tulokset Kuvassa 5. Silmämääräisessä tarkastelussa rehuissa ei havaittu homekasvustoja.

Hiivakasvustojen runsaus rehunäytteissä

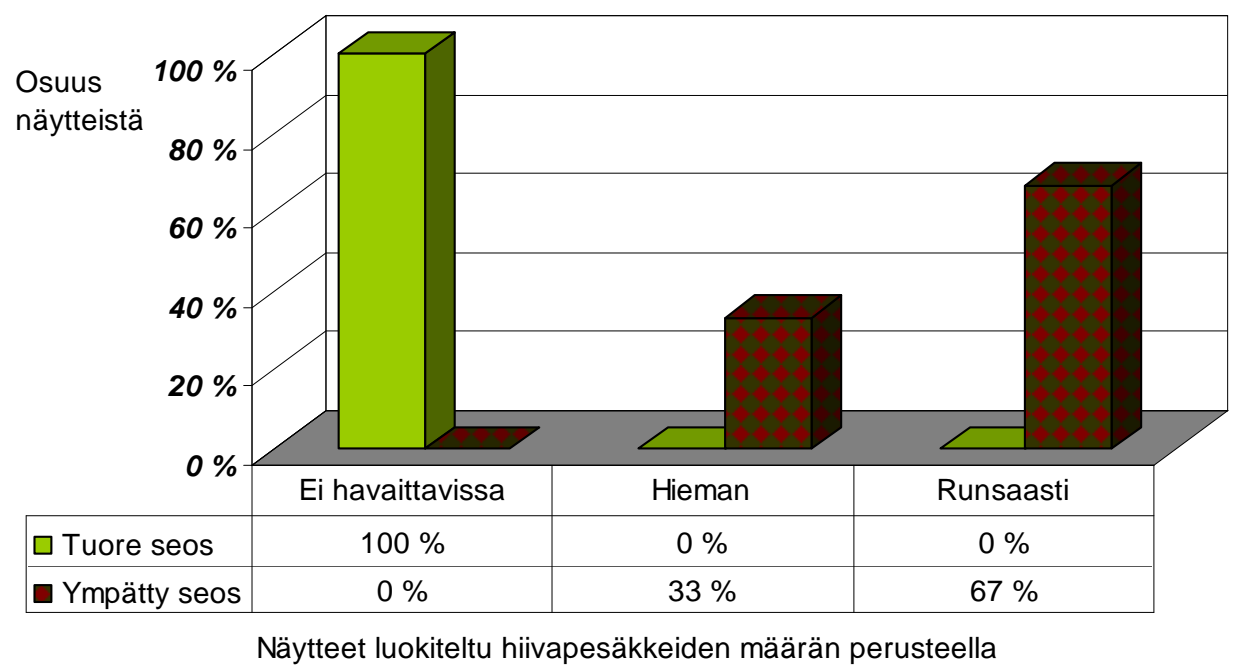

Kuva 5. Kuuden vuorokauden aerobisen vaiheen aikana seosrehuun ilmestyneiden hiivakasvustojen määrä arvioitiin silmämääräisesti. 


\section{Tulosten tarkastelu}

Tässä kokeessa tuore seos tehtiin raaka-aineista, joiden laatu oli moitteeton. Näin saavutettu aerobinen stabiilisuus ( 2 vrk ja 18 h) oli pidempi kuin mitä maatilamittakaavassa yleensä on mahdollista saavuttaa. Jonkin verran mikrobikontaminaatiota tapahtuu käytännön mittakaavassa joka tapauksessa seosrehuvaunun rakenteista sekä ruokintapöydältä. Ympätyn seosrehun aerobinen stabiilisuus sen sijaan vastaa Kungin (2005) havaintoja maatilamittakaavan seosrehujen pilaantumisherkkyyksistä. Kungin tutkimusryhmä keräsi 30 näytettä seosrehuista maatiloilta ja testasi niiden aerobisen stabiilisuuden. Tutkituista seoksista yli 50 \% lämpeni selvästi alle 12 tunnin kuluessa. Samassa tutkimuksessa havaittiin lineaarinen yhteys seosrehun aerobisen stabiilisuuden ja hiivojen lukumäärän välillä. Tämä tukee havaintojamme hiivakasvustoista sekä ymppimateriaalissa että ympätyssä seoksessa.

Kuiva-ainetappioiden suuruus olisi mielekkäämpää mitata 1- 2 vuorokauden kuluttua seosrehun sekoittamisesta. Tällöin tuloksen perusteella voisi tehdä myös päätelmiä rehun lämpenemisen taloudellisesta vaikutuksesta maatilamittakaavassa. Myös rehujen väliset erot tulisivat paremmin esille.

Tässä kokeessa ei saatu kovin isoa parannusta seosrehun aerobiseen stabiilisuuteen tutkituilla säilöntäaineilla. Kungin ym. (1998) tutkimuksessa propionihappopohjainen säilöntäaine TMR-Mate ${ }^{\mathrm{TM}}$ paransi selvästi säilörehun aerobista stabiilisuutta jo annostelutasolla $2 \mathrm{~g} / \mathrm{kg}$, kun se lisättiin rehuun jo säilöntävaiheessa. Sen sijaan, kun tuota valmistetta lisättiin seosrehuun, ei sama annostelutaso riittänyt. Annostelutasolla $3 \mathrm{~g} / \mathrm{kg}$ saatiin hillittyä rehun lämpenemistä ruokintapöydällä, mutta vaikutusta syönnissä tai maitotuotoksessa ei havaittu. Mahdollisesti on kustannustehokkaampaa parantaa säilörehun aerobista stabiilisuutta kuin lisätä säilöntäaineita seosrehuun (Kung 2005). Käyttömäärillä 1-3 $\mathrm{g} / \mathrm{kg}$ propionihappoon perustuvuen säilöntäaineiden teho on parantunut annostelutason kasvaessa (Kung ym. 1998 ja 2000).

\section{Johtopäätökset}

Tämän kokeen tulos osoittaa selvästi, miten merkittävää seosrehun laadun kannalta on, että pilaantuneen vanhan rehun ei anneta ympätä tuoretta seosta rehuvaunussa. Myös pilaantuneiden rehuerien (esimerkiksi pilaantuneet säilörehukohdat) joutuminen seokseen pitäisi estää. Lisäksi ruokintapöydän puhdistaminen vanhasta rehusta on tärkeää, sillä vanha rehu toimii pilaajamikrobien ymppimateriaalina nopeuttaen rehun pilaantumista. Tässä kokeessa käytetyillä säilöntäaineilla pystyttiin hieman hidastamaan seosrehun lämpenemistä. Käytetyt annostelumäärät olivat kuitenkin pieniä, eikä saavutettu aerobisen stabiilisuuden parantuminen ollut käytännön kannalta merkittävä. Seosrehun raakaainekoostumuksen ja säilöntäaineiden annostelumäärän vaikutusta seosrehun aerobiseen stabiilisuuteen pitäisi vielä tutkia. Ruokintakokeen avulla tulisi selvittää, mikä käytännössä on seosrehun lämpenemisen aiheuttama taloudellinen haitta. Sen perusteella olisi mahdollista arvioida aerobisen stabiilisuuden parantamiseksi tehtävien toimenpiteiden taloudellinen mielekkyys.

\section{Kirjallisuus}

Broderick G.A., Adesogan, A.T., Bocher, L.W., Bolsen, K.K., Contreras-Govea, F.E., Harrison, J.H. \& Muck, R.E. 2009. Proceedings XVth international silage conference, July 27-29, 2009 Madison, Wisconsin, USA. U.S. Dairy Forage Research Center: USDA-Agricultural Research Service. $501 \mathrm{~s}$.

Hoffman, P.C. \& Ocker, S.M. 1997. Quantification of milk yield losses associated with feeding aerobically unstable high moisture corn. Journal of Dairy Science Vol 80, Suppl.1 s. 234.

Kung L, Sheperd AC, Smagala AM, Endres KM, Bessett CA, Ranjit NK, Glancey JL. 1998. The effect of preservatives based on propionic acid on the fermentation and aerobic stability of corn silage and a total mixed ration. Journal of dairy science Vol. 81: 5: 1322-1330

Kung L, Robinson JR, Ranjit NK, Chen JH, Golt CM, Pesek JD 2000. Microbial populations, fermentation end-products, and aerobic stability of corn silage treated with ammonia or a propionic acid-based preservative. Journal of dairy science Vol. 83: 1479-1486.

Kung, L. Jr. 2005. Aerobic Stability of Silages. Proc. of the Conference on Silage for Dairy Farms. Harrisburg, PA. 2005 http://ag.udel.edu/anfs/faculty/kung/documents/05AerobicStability.pdf

McDonald, P., Henderson, N. \& Heron S. 1991. The Biochemistry of Silage. Second edition, Marlow : Chalcombe Publications. 340 s. ISBN 0-948617-22-5

Pahlow G. \& Muck, R.E. 2009. Managing for improved aerobic stability. Julkaisussa: Glen A. Broderick et al. Proceedings XVth international silage conference, July 27-29, 2009 Madison, Wisconsin, USA. U.S. Dairy Forage Research Center: USDA-Agricultural Research Service. s. 77-90. 